\title{
Value Co-creation and Leadership: An Analysis Based on the Business Ecosystem Concept
}

http://doi.org/10.21272/bel.3(4).66-73.2019

Andrei Bonamigo, ORCID: http://orcid.org/0000-0002-6670-9755

Dr in Production Engineering, Professor, Production Engineering Department, Fluminense Federal University, Volta Redonda, RJ, Brazil

Dayse Mendes, ORCID: https://orcid.org/0000-0001-5750-438X

MSc, Full Professor, International University Center, Curitiba, PR, Brazil

\begin{abstract}
This paper summarizes the arguments and counterarguments of the scientific discussion on multi-company co-operation leading, given that co-creating value between companies is a survival strategy for organizations by boosting competitiveness jointly several players. However, in the literature, the empirical characterization of value creation management in service companies is little explored. Therefore, the main objective of the research is to list the key factors for managing value co-creation in an industrial service company. To achieve this goal, an on-site interview was conducted with the leaders of a business-consulting firm whose business strategy is to cooperate with multiple players. The company object of research is located in southern Brazil, in the state of Santa Catarina. Once data collection was conducted, then content analysis was conducted. Based on the research findings, eleven key criteria that characterize cooperation between companies in the business consulting area were listed. It was found that value co-creation had several advantages for the company studied, however, lack of trust is one of the critical and risk factors for cooperation with other companies. Thus, it can be seen that leadership strategies are a key element for meeting potential business partners to co-create value as well as for managing cooperation between multiple companies. Given the findings, some practical implications can be highlighted. The study can serve as a basis for managers and leaders to make strategic business decisions, guide business leadership in driving plans to capture new business partners reliably and that together can generate mutual value. In addition, it is clear that the studied company's system in relation to knowledge management is fragile since there is no structured system to control and disseminate knowledge internally and externally to the analyzed company. Thus, this research allows us to identify new insights to advance in studies related to the leadership of value co-creation among companies.
\end{abstract}

Keywords: Leadership, Value co-creation; Business consulting; Multi-agent cooperation; Innovation; Industrial service management.

JEL Classification: D46, O3, L8.

Cite as: Bonamigo, A., Mendes, D. (2019). Value Co-creation and Leadership: An Analysis Based on the Business Ecosystem Concept. Business Ethics and Leadership, 3(4), 66-73. http://doi.org/10.21272/bel.3(4).66-73.2019.

(C) The Authors, 2019. This article is published with open access at Sumy State University.

\section{Introduction}

Business-to-business cooperation proves to be a motivator for companies to interact and jointly create value in the business environment in which they operate. In this sense, the interaction between various companies emerges as a paradigm break in recurring theories, such as Supply Chain Management (SCM) (Bonamigo, 2017).

The lack of management among multiple actors, from a descriptive, prescriptive and evaluative holistic view of management practices in the industrial services sector is a gap that the theory presents (Frost and Lyons, 2017). This sense, companies can rarely maintain or increase their competitiveness on their own. In this sense, the strategic need arises for companies to collaborate with industrial services SMEs, within an organizational arrangement based on the cooperation between multiple actors of the industrial services business environment.

Companies can rarely maintain or increase their competitiveness on their own. Thus, the strategic need arises for companies to collaborate with industrial services SMEs, within an organizational arrangement based on 
the cooperation between multiple actors of the industrial services business environment (Moore, 1996; Bonamigo, Ferenhof, Forcellini, 2016a; Witolla, Sames, Greig, 2016; Bonamigo, 2017).

In the industrial services business environment, the lack of cooperation and interaction between manufacturing, service providers, service facilitating companies, government agencies, universities, research, and logistics institutes proves to be a barrier to the industry in terms of competitiveness, innovation and value sharing among actors who together created value (Gruber and Frugone, 2011; Frost and Lyons, 2017; Edvardsson et al., 2018).

On the other hand, co-creation can be an obstacle to the organization's development due to the waste of knowledge (Ferenhof, 2015; Ferenhof, Bonamigo, Forcellini, 2016), as well as below-expected benefits from co-creation (Jaakkola and Aarikka-Stenroos, 2018), delay gaining through cooperation (Virtanen, Parvinen, Rollins, 2015), and unnecessary processes and/or operations that limit value co-creation in services (Breidbach and Maglio, 2016; Steinbach, Wallenburg et al., 2018; West et al., 2018).

Given the exposed, this study aims to list the key factors for managing value co-creation in an industrial service company. Based on the findings, it is possible to develop tools and techniques for managing value creation in industrial service companies.

Once the criteria identified in practice are listed, it will be possible to confront the literature for a better understanding of the criteria presented empirically about the relevance criteria presented by the theory.

\section{Industrial Services Ecosystems}

The service industry is regarded as a dynamic component that is essential for companies manufacturing and generate value from the customer's perspective. (Ballantyne and Aitken, 2007; Artto et al., 2015; Bao and Toivonen, 2015; Ambroise et al., 2018).

Notwithstanding the growing importance of industrial service companies, little is known about how these services work and even less about how they interrelate with manufacturing companies. (St-Pierre et al., 2008; Kohtamaki and Partanen, 2016).

To approach the industrial services environment from a holistic perspective, we chose to use the business ecosystem concept, that is, the business ecosystem concept.

The business ecosystem has its genesis in the ecology theory. As in natural systems, the business ecosystem must attract different types of resources and transform them so that value is co-created (Moore, 1993).

This concept aims at co-creating value among business environment actors through symbiosis, a term derived from biology, which comprises the interaction between two different organisms living in close association, which generally has advantages for them (Moore, 1993; Lamprinopoulou et al., 2014; Bonamigo, Ferenhof, Forcellini, 2016b; Grott et al., 2019).

Value co-creation in industrial service companies is limited to business-to-business (B2B) business, ie, between companies, as a focal company with cooperatives, universities, research centers, city hall, unions, banks, and agro-industries.

In this sense, the actors who seek value co-creation need organizations to manage this process to list the points that need to be addressed (i.e. what to do). To Prahalad and Ramaswamy (2004), four elements are fundamental to value co-creation: Dialogue, Access, Risk and Transparency (DART).

However, Grönroos (2012) highlights the metaphorical character of value co-creation and defines a model that brings together the basic elements to understand, plan and provide input to interactions between cooperating actors in the business environment, so that both actors that cooperate have a perception of value together complement each other.

Based on the mentioned model, it is evident that the co-created value comes from the sharing of resources, in which the author who acts individually is limited (Da Silva et al., 2015; Fernando and Las Casas, 2018). These shared resources can be knowledge, technology, infrastructure, monetary values, and people.

\subsection{Knowledge Management in Business Consulting Services as a Business Strategy}

According to Alves and Monsores (2015), business consulting is a service where professionals help others with their experience and knowledge, to enable companies to grow and stay in the market. In this sense, for small companies that do not have technological potential, consulting becomes essential. 
Consulting enables the knowledge exchange and dissemination of concepts still lacking in companies, their broad understanding adapted to a certain condition and management model's application to improve processes, products, and services in different types of organizations (Silva, 2004).

Thus, knowledge shared at interaction through consulting can help the company better organize its strategies in order to manage knowledge to generate competitive advantages in the knowledge Age that we face today (Carvalho, 2012), one of the biggest hurdles companies face is how to manage tacit knowledge.

For Carvalho (2012), tacit knowledge management, that is, the knowledge that the person acquires during life, is a key element for competitiveness and the creation of a knowledge-based strategy. In this context, consulting allows you to add value and make the company competitive in an increasingly competitive market, which depends on the effective management of its intellectual assets.

Thus, the exchange of knowledge disseminated in the business consulting service appears as a strategic resource for organizations in the dynamic environment in which they find themselves. To achieve better performance and competitive sustainability knowledge management, physical and personnel resources become strategic factors that require planned guidance management to generate value for the organization (Shahzad et al., 2016).

According to Shahzad et al., (2016), some considerations can be highlighted about knowledge management as a competitive advantage, among them: the strategy has potential impact for better use and application of tacit knowledge of the company members; allows the involvement of company members from different areas to integrate; motivates the creativity and innovation based on the knowledge of multiple employees from different areas of the company.

\subsection{Value Co-creation at Industrial Service Ecosystem}

According to Brambilla and Damacena (2012), co-creation is essential for value generation. In this sense, the authors characterize this generation of value in university education, in which institutions and students should be concerned with the effective result of the service, by developing expected skills, such as cognition and logical reasoning.

On the one hand, students are concerned with learning (or developing the skills needed for the job market) and not failing. Thus, the experience of this co-creation process will be satisfactory. On the teacher's side, the goal is for students to develop skills and to evaluate them positively (Brambilla and Damacena, 2012).

For the institution, it is important that students have developed the skills provided, which can be proved in government tests, and that the student does not leave the institution and can be an indicator of potential students (in prospecting students). The whole of society needs professionals who are capable of solving daily tasks, and in the case of business, examples such as running companies and organizations make clear the importance of better co-created results in preparing these future workers. (Brambilla and Damacena, 2012),

Based on the characterization presented by Brambilla and Damacena (2012), it is observed that the active and interactive presence of both players is fundamental for the cooperation to generate advantages for the cooperating actors, tangible gains and/or intangibles.

However, it can be emphasized that knowledge (intangible gain) increasingly tends to become a wealth differential in any area, with the base pillar being shared knowledge management and co-creation among multiple companies. Thus, multi-actor interaction drives sustainability, and innovation and economic gains for both actors that together create value in the industrial service system (Weersma et al., 2019).

\section{Methodological Procedures}

This study aims to list the key factors for managing value co-creation in an industrial service company.

The consulting firm studied here in the study entitled ABC Company is located in the Santa Catarina Midwest/Brazil.

ABC provides consulting services to small and medium-sized companies in the areas of production management, quality management, financial management, business risk management, and strategic planning. To achieve this goal, five steps are proposed. 
The first step was to identify in the literature constructs and foundations about value co-creation in the industrial services environment. To achieve this objective, an exploratory literature search was conducted, based on articles from scientific journals, master's dissertations and doctoral thesis.

In the second step of the study, an instrument for data collection was built in the company. Through the semi-structured questionnaire, data collection was conducted. At this stage, the company directors were interviewed, who also act as consultants of the company. Additionally, at this stage, two pilot tests were conducted a priori with experts in the field to calibrate the instrument. Adjustments have been incremented on the instrument.

The third step comprised the application of the data collection instrument in practice, by prior appointment with each interviewee. Once data were collected, the fourth step of the study was conducted, which comprises content analysis.

Content analysis was based on Bardin (2011), based on the analysis units defined a posteriori. In this step, based on the portfolio resulting from the content analysis, it was possible to recognize the factors judged as critical for the partner's selection for value creation in the industrial service provider company, in this study analyzed.

\section{Results and Discussions}

ABC Company is located in the Midwest of Santa Catarina/Brazil and serves customers throughout the state in activities related to administrative management and production management, with emphasis on human development. The services provided by the company occur on-site at the customer's premises.

Once the collection instrument was applied in practice, it was possible to obtain the findings presented in Table 1 . In the company studied, the three shareholders of the company were interviewed, here in the study entitled: director "A", director "B" and director "C".

From the interview, the respondents' answers were first transcribed, to later conduct the content analysis phase. In this phase, the context units were identified and transcribed in Table 1.

After listing all the context units, they were organized by approximation to define the analysis units. It is noteworthy that the units of analysis were defined as the posteriori (Table 1).

Table 1. Content Analysis

\begin{tabular}{|c|c|}
\hline nit & $\mathrm{It}$ \\
\hline $\begin{array}{l}\text { Value } \\
\text { co-creation } \\
\text { frequency }\end{array}$ & $\begin{array}{l}\text { When questioning the entrepreneurs about acting cooperatively with other companies, director "B" pointed out } \\
\text { that "the company has been acting for several years in this way with two partners, which we constantly seek to } \\
\text { co-create value. One comprises a class association and the other a management software development } \\
\text { company". } \\
\text { Besides, directors "A" and "C" commented that "this interaction and exchange is frequent, the periodicity in } \\
\text { some periods is weekly". }\end{array}$ \\
\hline & $\begin{array}{l}\text { Directors "A" and "C" agreed that the advantages of cooperation are related to the exchange of experiences, } \\
\text { knowledge, insights into new service offering opportunities, tips for improving service delivery, developing } \\
\text { joint solutions, and pointing out opportunities. of new business. } \\
\text { Then, the director "B" stated that "via cooperation it was possible to expand the improvement in the market } \\
\text { they operate, the exchange of experience causes professional growth." } \\
\text { Director "A" later pointed out that "his and his personal and professional growth has been of great } \\
\text { importance to us, the partners we have had for years with us. Together we help each other, and at any moment } \\
\text { we have someone to count on". }\end{array}$ \\
\hline $\begin{array}{lr}\text { for } \\
\text { g a }\end{array}$ & $\begin{array}{l}\text { er must have a clear } \\
\text { er most important, }\end{array}$ \\
\hline & $\begin{array}{l}\text { Both pointed: People who want to benefit from something and give nothing in return, without help, without } \\
\text { collaboration. In this regard, director "B" pointed out that he had "an experience in the city (....) which } \\
\text { supported a new partner, but at the time of receiving the benefit the other party left me in the hand. We spend } \\
\text { hours of work, commuting and we are at a loss". }\end{array}$ \\
\hline $\begin{array}{l}\text { Cooperation } \\
\text { with positive } \\
\text { experiences }\end{array}$ & $\begin{array}{l}\text { rector "C" replied that "the participation beginning in the class association leaves us surrounded by people, } \\
\text { repreneurs, with interest to generate value together. This is a first step as we begin to map potential partners } \\
\text { the future. }\end{array}$ \\
\hline
\end{tabular}




\begin{tabular}{|c|c|}
\hline $\begin{array}{l}\text { Cooperation } \\
\text { with negative } \\
\text { experiences }\end{array}$ & $\begin{array}{l}\text { Director "C" reported a fact of an attempt to cooperate with another consulting firm, which began at a meeting } \\
\text { during a management event. "Unfortunately, this attempt to cooperate was a big mistake. The "competitor" } \\
\text { caught a potential demand that was directed at us". Subsequently, directors A and B reinforced the "need to } \\
\text { know in-depth the principles and values of the individual and company, as well as recognize the purpose and } \\
\text { vision of the other party interested in cooperating". } \\
\text { In addition, Director "C" reported that "we have those new college "novice" consultants knocking on our } \\
\text { door, we try not to pay much attention, because at the beginning we had a lot of wasted effort with this profile } \\
\text { of people, they leave college and start a consulting company thinking that " they know everything "I think } \\
\text { there is a lack of experience and a bit of ground to think about partnering with us in the future. The } \\
\text { experiences were not good with these novices". }\end{array}$ \\
\hline $\begin{array}{l}\text { Investment in } \\
\text { cooperation } \\
\text { and value co- } \\
\text { creation }\end{array}$ & $\begin{array}{l}\text { Together the directors pointed out that the biggest "investments we have made are the "time" to participate in } \\
\text { meetings organized by the association, meetings at the partner or right here in our office, as well as cell phone } \\
\text { messaging, email and occasionally some phone calls". }\end{array}$ \\
\hline & $\begin{array}{l}\text { several channels are used, but mainly Skype, WhatsApp, in person. They recently } \\
\text { uts. }\end{array}$ \\
\hline $\begin{array}{l}\text { Partner } \\
\text { Feedback }\end{array}$ & $\begin{array}{l}\text { In arguing about some means of giving and receiving feedback from partners, director "A" and "B" pointed } \\
\text { out that it is a weakness that they and partners have. "Our feedback is often tied to thanks from a tip, from a } \\
\text { conversation. Everything is Informal, we need to rethink this, it was worth our conversation to question this } \\
\text { for us". }\end{array}$ \\
\hline $\begin{array}{l}\text { Difficulties for } \\
\text { new } \\
\text { partnerships }\end{array}$ & $\begin{array}{l}\text { Director "A" pointed out that the "long time to close sales so that the partner gets involved in demand is a big } \\
\text { issue for us. As it is a service, companies often take six months to close a partnership, this often shows } \\
\text { motivation at the beginning when they see opportunity and advantages for them". } \\
\text { Director "C" pointed out that the partners, "especially the freelance consultants, expect emergency results and } \\
\text { put pressure on our work system, so we have already started badly, we opted to remove this stakeholder from } \\
\text { the business. The customer has his time, we need to respect that so as not to lose the business or even be } \\
\text { "boring" with the customer". } \\
\text { Director "C" commented that "people want rapid growth and end up giving up cooperation. Unfortunately, } \\
\text { the immediacy you see today is not always beneficial for business, as in our case for business consulting } \\
\text { services". }\end{array}$ \\
\hline $\begin{array}{l}\text { Improv } \\
\text { Opport }\end{array}$ & $\begin{array}{l}\text { In asking directors about the sufficient support they receive from other agents or business partners to enhance } \\
\text { their service and business, director's "B" and "C" point out that Director "A" felt that "building trust, } \\
\text { patience, and trust in the partner is critical to delivering a better benefit to our customer, and all of us, the } \\
\text { company and the partner benefit each other. I think cooperation is important these days, but we need to be } \\
\text { careful who is by our side to help or just to take advantage of the business partnership". }\end{array}$ \\
\hline
\end{tabular}

Source: Elaborated by the authors (2019)

Regarding the "frequency of value co-creation", it can be seen that the studied company acts cooperatively in the pursuit of co-creating value so that other agents other than the end-company activity can contribute and generate mutual benefits (Ikenami and Salerno, 2015; Guo and Bouwman, 2016; Kohtamäki and Partanen, 2016; Yang and Tang, 2016).

In this respect, a company's performance converges with the business ecosystem concept approach, which includes a set of players that form the coupling generate mutual benefits in the ecosystem in which they are inserted (Moore, 1996; Peltoniemi, 2006; Li, 2009; Koenig, 2012).

Regarding the "advantages of cooperation", it can be seen that the exchange of experiences, knowledge, development of joint solutions and indications of new business opportunities are benefits that actors derive from interaction in an iterative manner (Bonamigo, 2017).

On the other hand, although not mentioned by respondents, cooperation can create business risks by wasting knowledge (Peltoniemi, 2005; Li et al., 2014).

In this respect, Ferenhof; Bonamigo e Forcellini (2016) highlights the need to define strategies to ensure that knowledge, i.e. the intellectual property of the company, is not wasted or illegally captured by the partner. Thus, it can generate "cooperation with negative experiences", as well as compromise the company, by leaking the knowledge that it has mastery.

Thus, "criteria for selecting a new partner" are fundamental when it comes to trust, sharing the same vision, and the values that both players share (Klen, 2009).

Also, "cooperation with positive experiences" can be facilitated as developing trust in the partner is one of the most challenging barriers, as mentioned by the company studied directors.

Still, it can be seen that one of the advantages of the company analyzed is that the "Investment in cooperation" was low, only the player's time to participate in periodic meetings. Thus, it can be seen that in 
Business Ethics and Leadership, Volume 3, Issue 4, 2019 ISSN (online) - 2520-6311; ISSN (print) - 2520-6761

the consultancy company analyzed, the value creation contributes to maximizing the gains with low investments. That is, value co-creation can be seen as an attractive competitive differential for the business being analyzed (Minh and Hjortsø, 2015).

Regarding the "Communication Channels" and "Partner Feedback", it can be seen that they can be relatively complementary, as long-term proximity can drive informal feedback to the partner, however it is a risk. generalize this practice to other conditions, due to the long-term characteristics that exist between the studied company and its business partners (Peltoniemi, 2006; Karvonen; Conte, 2012; Fischer, 2014).

Although the directors point out 'Difficulties for new partnerships' as well as 'Opportunities for improvement' for the ecosystem in which they operate, it is worth noting that the characterization in which the directors pointed out is common in the business ecosystem, given the values and principles that each player adopts in their business policies (Fischer, 2014).

However, continuous improvement is a fundamental construct to be guided and enhanced in the multiplayer relationship, as industry dynamics change, customer needs change over time, and perceived value in service needs to be addressed (Zokaei and Simons, 2006; Womack and Jones, 2010; Powell et al., 2017; Werner, 2017).

\section{Conclusion}

This study aims to list the key factors for managing value co-creation in an industrial service company. Based on the study findings, one can characterize a business consulting firm. Regarding the practices adopted to leadership and select key partners for co-creation, as well as strategies used for the management of these players.

It was found that value co-creation in the company studied has generated mutual gains for long-term partners who mutually cooperate with it, in addition to low costs and/or investments in value co-creation. On the other hand, some negative experiences were identified, due to the opportunism that some partners aimed at the company so that waste was generated in the value creation.

From this study, contributions are evidenced, among them: assisting managers in decision-making regarding the co-creation of value creation in companies, developing strategies to mitigate losses in value co-creation, as well as boosting the search for new business partners so that both identify gains from value co-creation.

As a limitation of this study, it is noteworthy that the study was limited to a single case, a factor that cannot generalize the results, as well as validate the respondents' answers.

As opportunities for future studies, it is recommended to apply the study with a larger sample size, as well as to propose a model for managing value co-creation in industrial service consulting firms. Also, it is suggested to articulate the criteria identified in the business-consulting sector in other segments of industrial services such as industrial maintenance and industrial training.

\section{References}

1. Alves, J. D. C., Dias, N. T., Monsores, G. L. (2015). Consultoria empresarial como ferramenta estratégica de desenvolvimento em pequenas empresas [Business consulting as a strategic tool for small business development]. Anais do XII Simpósio de excelência em gestão e tecnologia-SEGeT, Rezende, RJ, Brasil.

2. Ambroise, L., Prim-Allaz, I., Teyssier, C., \& Peillon, S. (2018). The environment-strategy-structure fit and performance of industrial servitized SMEs. Journal of Service Management, 29(2), 301-328. Doi:10.1108/JOSM-10-2016-0276.

3. Artto, K.; Valtakoski, A.; Kärki, H. (2015). Organizing for solutions: How project-based firms integrate project and service businesses. Industrial Marketing Management, 45(1), $70-83$. https://doi.org/10.1016/j.indmarman.2015.02.021.

4. Ballantyne, D., Aitken, R. (2007). Branding in B2B markets: insights from the service-dominant logic of marketing. Journal of Business \& Industrial Marketing, 22(6), 363-371. https://doi.org/10.1108/08858620710780127.

5. Bao, S., Toivonen, M. (2015). Cultural differences in servitization: Nordic manufacturers in China. Journal of Science and Technology Policy Management, 6(3), 223-245. https://doi.org/10.1108/JSTPM01-2015-0001.

6. Bardin, L. (2011). Análise de conteúdo [Content Analysis], 3. reimp. Lisboa: Ediçoes, Vol. $70,225$. Available https://edisciplinas.usp.br/pluginfile.php/4295794/mod_resource/content/1/BARDIN\%2C\%20L.\%20\%28 $1977 \% 29 . \% 20$ An\%C3\%A1lise\%20de\%20conte\%C3\%BAdo.\%20Lisboa_\%20edi\%C3\%A7\%C3\%B5es $\% 2 \mathrm{C} \% 2070 \% 2 \mathrm{C} \% 20225$..pdf. 
ISSN (online) - 2520-6311; ISSN (print) - 2520-6761

7. Bonamigo, A. (2017). A management model for dairy production based on the ecosystem business concept, 141p. (Doutorado). Engenharia de Produção, Universidade Federal de Santa Catarina, UFSC, Florianópolis. Available at: https://repositorio.ufsc.br/handle/123456789/187561.

8. Bonamigo, A., Ferenhof, H. A., Forcellini, F. A. (2016a). Applicability analysis of the business ecosystem concept in dairy production based on a systematic literature review. II Simpósio Internacional de Inovação em Cadeias do Agronegócio. Caxias do Sul. agosto 26, 2016 - agosto 27, 1-10. Available at: http://www.ucs.br/etc/conferencias/index.php/IIsimposioinovacaoagronegocio/simposioinovacaoagroneg ocioucs/paper/viewFile/4594/1437.

9. Bonamigo, A., Ferenhof, H. A., Forcellini, F. A. (2016b). Applicability analysis of the business ecosystem concept in dairy production based on a systematic literature review. In: CRUZ, M. R. D.; SEVERO, E. A., et al (Ed.). Inovação e tecnologia no agronegócio como alternativa para a economia do Brasil - II SICPA. Caxias do Sul, RS: Educs, 1(30), 365-374.

10.Breidbach, C. F., Maglio, P. P. (2016). Technology-enabled value co-creation: An empirical analysis of actors, resources, and practices. Industrial Marketing Management, 56(1), $73-85$. https://doi.org/10.1016/j.indmarman.2016.03.011.

11.Edvardsson, B., Frow, P., Jaakkola, E., Keiningham, T. L., Koskela-Huotari, K., Mele, C., \& Tombs, A. (2018). Examining how context change foster service innovation. Journal of Service Management, 29(5), 932-955. https://doi.org/10.1108/JOSM-04-2018-0112.

12.Ferenhof, H. A. (2015). Um modelo para identificar desperdícios de conhecimento relacionados à performance dos portfólios de projetos [A model for identifying knowledge waste related to project portfolio performance]. 250p. (Doutorado em Engenharia de Produção). Programa de Pós- Graduação em Engenharia de Produção, Universidade Federal de Santa Catarina, Florianópolis, Santa Catarina, Brasil. Available at: https://repositorio.ufsc.br/xmlui/handle/123456789/135770.

13.Ferenhof, H. A., Bonamigo, A., Forcellini, F. A. (2016). Ecossistema de negócios: o conhecimento pode estar em risco [Business ecosystem: Knowledge may be at risk]. In: MACEDO, M.; TEIXEIRA, C. S., et al (Ed.). Gestão do conhecimento e capital intelectual em habitats de inovação: Novas Edições Acadêmicas [Knowledge management and intellectual capital in innovation habitats: Novas Edições Acadêmicas], 1(1), chap. 2.

14. Fernando, J. T., Las Casas, A. L. (2018). A cocriação de valor aplicada ao mercado industrial: estudo de caso na empresa Kerry do Brasil [Value co-creation applied to the industrial market: Case study in Kerry do Brasil company]. Revista de Administração, 16(1), 102-120. Doi: http://dx.doi.org/10.15600/rau.v16i1.1295.

15.Fischer, B. B. (2014). Confiança, sistemas de certificação e atributos intrínsecos em relacionamentos interorganizacionais: uma discussão teórica orientada para o ambiente dos agronegócios [Trust, certification systems, and Intrinsic attributes in inter-organizational relations: A theory-oriented discussion for the Agribusiness Environment]. RACE-Revista de Administração, Contabilidade e Economia, 13(2), 549-570. Available at: https://portalperiodicos.unoesc.edu.br/race/article/view/4134.

16.Frost, R., Lyons, K. (2017). Service systems analysis methods and components: a systematic literature review. Service Science, 8(3), 219-234. https://doi.org/10.1287/serv.2017.0180.

17.Grönroos, C. (2012). Conceptualising value co-creation: A journey to the 1970s and back to the future. $\begin{array}{llrl}\text { Journal of Marketing } \quad \text { Management, } & \text { 28(13-14), }\end{array}$ https://doi.org/10.1080/0267257X.2012.737357.

18.Grott, E. M., Cambra-Fierro, J., Perez, L., \& Yani-de-Soriano, M. (2019). How cross-culture affects the outcomes of co-creation. European Business Review, 31(4), 544-566. https://doi.org/10.1108/EBR-012018-0022.

19.Gruber, T., Frugone, F. (2011). Uncovering the desired qualities and behaviours of general practitioners (GPs) during medical (service recovery) encounters. Journal of Service Management, 22(4), $491-521$. https://doi.org/10.1108/09564231111155097.

20.Guo, J., Bouwman, H. (2016). An analytical framework for an m-payment ecosystem: A merchants' perspective. Telecommunications Policy, 40(2-3), 147-167. https://doi.org/10.1016/j.telpol.2015.09.008.

21.Ikenami, R., Salerno, M. (2015). Ecossistema de negócio: estudo exploratório acerca da delimitação de suas fronteiras [Business ecosystem: an exploratory study about the delimitation of its borders]. XXXV Encontro Nacional de Engenharia de Produção - ENEGEP. Perspectivas Globais para a Engenharia de Produção Fortaleza, CE, Brasil. Available at: http://www.abepro.org.br/biblioteca/tn_sto_213_261_27547.pdf.

22.Jaakkola, E., \& Aarikka-Stenroos, L. (2019). Customer referencing as business actor engagement behavior-Creating value in and beyond triadic settings. Industrial Marketing Management, 80(1), 27-42. https://doi.org/10.1016/j.indmarman.2018.06.014.

23.Karvonen, I., Conte, M. (2012). Supporting the enterprise collaboration (EC) and enterprise interoperability (EI) solution benefits by end-user involvement. International Journal of Product Development, 17(1-2), 139-152. https://doi.org/10.1504/IJPD.2012.051153.

24.Klen, E. R. (2009). Co-creation and Co-innovation in a Collaborative Networked Environment. In Working Conference on Virtual Enterprises, Springer, Berlin, Heidelberg, 33-40. https://doi.org/10.1007/978-3-642-04568-4_4. 
25.Koenig, G. (2012). Business ecosystems revisited. Management (France), 15(2), 208-224.

26.Kohtamaki, M., Partanen, J. (2016). Co-creating value from knowledge-intensive business services in manufacturing firms: The moderating role of relationship learning in supplier-customer interactions. Journal of Business Research, 69(7), 2498-2506. https://doi.org/10.1016/j.jbusres.2016.02.019.

27.Lamprinopoulou, C., Renwick, A., Klerkx, L., Hermans, F., \& Roep, D. (2014). Application of an integrated systemic framework for analysing agricultural innovation systems and informing innovation policies: Comparing the Dutch and Scottish agrifood sectors. Agricultural Systems, 129(1), 40-54. https://doi.org/10.1016/j.agsy.2014.05.001.

28.Li, X., Roberts, J., Yan, Y., \& Tan, H. (2014). Knowledge sharing in China-UK higher education alliances. International Business Review, 23(2), 343-355. https://doi.org/10.1016/j.ibusrev.2013.05.001.

29.Li, Y. R. (2009). The technological roadmap of Cisco's business ecosystem. Technovation, 29 (5), $379-386$. https://doi.org/10.1016/j.technovation.2009.01.007.

30.Minh, T. T., Hjortsø, C. N. (2015). How Institutions Influence SME Innovation and Networking Practices: The Case of Vietnamese Agribusiness. Journal of Small Business Management, 53(1), 209-228. https://doi.org/10.1111/jsbm.12189.

31. Moore, J. F. (1993). Predators and prey: a new ecology of competition. Harvard Business Review, 71(3), 75-86.

32.Moore, J. F. (1996). The death of competition: leadership and strategy in the age of business ecosystems. HarperCollins Publishers. Available at: http://www.herbrubenstein.com/articles/THE-DEATH-OFCOMPETITION.pdf.

33.Peltoniemi, M. (2005). Co-evolution in an organization population of which knowledge-intensive service organizations form a part. Services Systems and Services Management. Proceedings of ICSSSM'05, International Conference on IEEE. p.880-885. Doi: 10.1109/ICSSSM.2005.1500118.

34.Peltoniemi, M. (2006). Preliminary theoretical framework for the study of business ecosystems. $E: C O$ Emergence: $\quad$ Complexity and $\quad$ Organization, $\quad 8(1), \quad 10-19$. DOI: 10.emerg/10.17357.8bb81e60d0fa815f83002ae1f418068c.

35.Powell, D., Lundeby, S., Chabada, L., \& Dreyer, H. (2017). Lean Six Sigma and environmental sustainability: the case of a Norwegian dairy producer. International Journal of Lean Six Sigma, 8(1), 53-64. https://doi.org/10.1108/IJLSS-06-2015-0024.

36.Prahalad, C. K.; Ramaswamy, V. (2004). Co-creation experiences: The next practice in value creation. Journal of interactive marketing, 18(3), 5-14. https://doi.org/10.1002/dir.20015.

37.Silva, M. R. D., Borges, I. R., Pereira, G. M., Borchardt, M., \& Sellitto, M. A. (2015). Co-creation of value in road cargo transport: A case study. Producao, 25(2), 454-464. http://dx.doi.org/10.1590/01036513.014611.

38.St-Pierre, J., Raymond, L., Zouiten, S., \& Menvielle, W. (2008). Performance of industrial service SMEs: A Conceptual Framework and Diagnostic System. 11th Toulon-Verona Conference, Quality in Services, Sep 2008, Florence, Italy. Doi: 10.1400/96232.

39.Steinbach, T., Wallenburg, C. M., Selviaridis, K. (2018). Me, myself and I: Non-collaborative customer behavior in service outsourcing - the key role of outcome orientation and outcome attributability. International Journal of Operations \& Production Management, 38(7), 1519-1539. https://doi.org/10.1108/IJOPM-05-2017-0297.

40.Virtanen, T., Parvinen, P., Rollins, M. (2015). Complexity of sales situation and sales lead performance: An empirical study in business-to-business company. Industrial Marketing Management, 45(1), 49-58. https://doi.org/10.1016/j.indmarman.2015.02.024.

41.Werner, S. M. (2017). Proposta de um modelo de gestão para alta hospitalar baseado na abordagem lean [Proposal for a management model for hospital discharge based on lean-approach]. 173 (Mestrado). Engenharia de Produção e Sistemas, Universidade Federal de Santa Catarina, Florianópolis, Brasil. Available at: https://repositorio.ufsc.br/xmlui/handle/123456789/179794.

42.West, S., Gaiardelli, P., Resta, B., \& Kujawski, D. (2018). Co-creation of value in Product-Service Systems through transforming data into knowledge. IFAC-PapersOnLine, 51(1), 1323-1328. https://doi.org/10.1016/j.ifacol.2018.08.349.

43.Witolla, T., Sames, P., Greig, A. (2016). Vessels for the Future. Transportation Research Procedia, 14, 1641-1648. https://doi.org/10.1016/j.trpro.2016.05.129.

44.Womack, J. P., Jones, D. T. (2010). Lean thinking: banish waste and create wealth in your corporation. Simon and Schuster. Journal of the Operational Research Society, 48(11), 1148-1149. Doi:10.1038/sj.jors.2600967.

45.Yang, R., Tang, F. (2016.). Restructuring Business Ecosystem Via Internet Thinking. Management \& Engineering, 1(24), 16-23. Doi: 10.5503/J.ME.2016.24.002.

46.Zokaei, K., Simons, D. (2006). Performance improvements through implementation of lean practices: a study of the UK red meat industry. International Food and Agribusiness Management Review, 9(2), 30-53. Doi: 10.22004/ag.econ.8194. 